\title{
DES wt Allele
}

National Cancer Institute

\section{Source}

National Cancer Institute. DES wt Allele. NCI Thesaurus. Code C96449.

Human DES wild-type allele is located in the vicinity of 2 q35 and is approximately $8 \mathrm{~kb}$ in length. This allele, which encodes desmin protein, plays a role in muscle cell contraction. Mutation of the gene is associated with myopathy myofibrillar desmin-related, cardiomyopathy dilated type 1 I and neurogenic scapuloperoneal syndrome Kaeser type. 